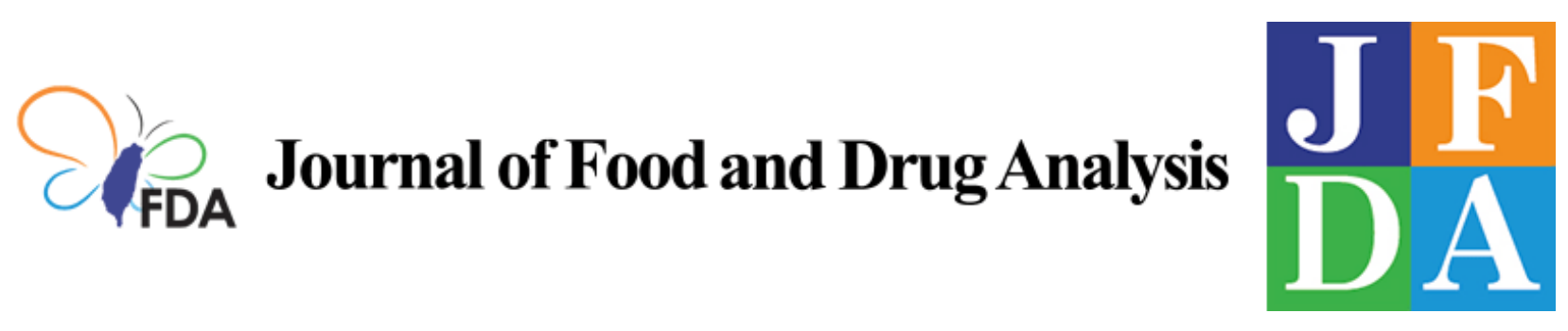

Volume 1 | Issue 4

Article 1

1993

\title{
Sedative-Hypnotics: Addiction and Current Research Status
}

Follow this and additional works at: https://www.jfda-online.com/journal

\section{(c) (1) (9)}

This work is licensed under a Creative Commons Attribution-Noncommercial-No Derivative Works 4.0 License.

\section{Recommended Citation}

Tseng, Yi-Tang; Wellman, Susan E.; and Ho, I. K. (1993) "Sedative-Hypnotics: Addiction and Current Research Status," Journal of Food and Drug Analysis: Vol. 1 : Iss. 4 , Article 1.

Available at: https://doi.org/10.38212/2224-6614.3068

This Original Article is brought to you for free and open access by Journal of Food and Drug Analysis. It has been accepted for inclusion in Journal of Food and Drug Analysis by an authorized editor of Journal of Food and Drug Analysis. 


\title{
Sedative-Hypnotics: Addiction and Current Research Status
}

\author{
YI-TANG TSENG, SUSAN E. WELLMAN AND I. K. HO \\ Department of Pharmacology and Toxicology, University of Mississippi Medical Center \\ Jackson, Mississippi 39216-4505, U.S.A.
}

\begin{abstract}
Central nervous system depressants, e.g. alcohol, barbiturates, and benzodiazepines, have a wide spectrum of activity in human and animals. These depressants produce varying degrees of CNS depression, depending mainly upon the dose used. In small doses, they can alleviate anxiety and/or reduce spontaneous activity; in moderate doses, they induce sleep; with large doses, severe CNS depression progresses to anesthesia, coma or even death. This graded, dose-dependent CNS depression is a common feature of these agents. In addition to causing CNS depression, these agents also possess other pharmacological properties, e. g. muscle relaxation, anticonvulsant activity, respiratory depression, hypothermia, etc.

Tolerance-dependence developing to sedative-hypnotics is a common feature following continuous administration of sedative-hypnotics. Tolerance is defined as a decreasing response to repeated administration of the same dose of a sedative-hypnotic or as a necessary increase of the dosage to obtain the initial response. There are two types of tolerance-one dispositional (pharmacokinetic), the other functional (pharmacodynamic). Dependence is defined as a modification of physiological functions that require continuous drug adiministration to prevent the appearance of withdrawal symptoms. Abrupt withdrawal from long-term usage of these drugs may produce anxiety, dizziness, nausea and vomiting, insomnia, muscular twitching, hyperthermia, delirium, tremors, convulsions, and death.

Evidence accumulated suggests that some of the pharmacological actions exerted by sedativehypnotics, e.g benzodiazepines, barbiturates and alcohol, may be mediated through the GABA system by mimicking GABAergic transmission. However, the mechanisms of the actions of these agents on the GABA system remain to be elucidated. Benzodiazepines have been demonstrated to have receptors which are parts of the GABAA receptors (GABA benzodiazepine receptor chloride ionophore complexes). Although a definitive barbiturate binding site has not yet been identified, the available evidence strongly suggests that barbiturate binding sites and convulsant binding sites are separate but allosterically affect each other. As far as ethanol is concerned, it is likely that multiple neurotransmitter systems are affected. Therefore, it is still unclear how alcohol, barbiturates, and benzodiazepines are functionally associated with the GABA system.

The evidence summarized demonstrates that the GABA synapse plays an important role in the pharmacologic effects of barbiturates, alcohol and benzodiazepines. There are similarities and differences in the effects of these CNS depressants on the pharmacology and biochemistry of the GABA synapse. The effects of alcohol, barbiturates and benzodiazepines on GABA synapses are different in different brain regions. Furthermore, the results which have been reported in the litera-
\end{abstract}


ture are inconsistent. This may be due to differences in (a) animal models used, (b) brain regions used, (c) protocols used in treating the animals (dose, duration, form and route of administration, etc.) and/or (d) techniques used (pharmacological, biochemical, physiological, etc.)

Key words : Sedative-Hypnotics, CNS depressant, GABA, Benzodiazepines.

\section{INTRODUCTION}

Central nervous system (CNS) depressants, e.g. benzodiazepines (BDZ), barbiturates, and alcohol, have a wide spectrum of activity in human and animals. These depressants produce varying degrees of CNS depression, depending mainly upon the dose used. In small doses, they can alleviate anxiety and/or reduce spontaneous activity; in moderate doses, they induce sleep; with large doses, severe CNS depression progresses to anesthesia, coma or even death. This graded, dose-dependent CNS depression is a common feature of these agents. In addition to causing CNS depression, these agents also possess other pharmacological properties, e.g. muscle relaxation, anticonvulsant activity, respiratory depression, hypothermia, etc.

Development of tolerance-dependence to sedative-hypnotics is a common feature following continuous administration of sedative-hypnotics. Tolerance is defined as a decreasing response to repeated administration of the same dose of a sedative-hypnotic or as a necessary increase of the dosage to obtain the initial response. There are two types of tolerance - one dispositional (pharmacokinetic), the other functional (pharmacodynamic). Dependence is defined as a modification of physiological functions that require continuous drug adminstration to prevent the appearance of withdrawal symptoms. Abrupt withdrawal from long-term usage of these drugs may produce anxiety, dizziness, nausea and vomiting, insomnia, muscular twitching, hyperthermia, delirium, tremors, convulsions, and death.

Accumulated evidence suggests that some of the pharmacological actions exerted by BDZ, barbiturates, and alcohol may be mediated through the GABA system by mimicking GABAergic transmission. However, the mechanisms of the actions of these agents on the GABA system remain to be elucidated. Benzodiazepines have been demonstrated to have receptors that are parts of the $\mathrm{GABA}_{\mathrm{A}}$ receptors (GABA-BDZ receptor chloride ionophore complexes). Although a definitive barbiturate binding site has not yet been identified, the available evidence strongly suggests that barbiturate binding sites and convulant binding sites are separate but allosterically affect each other. As far as ethanol is concerned, it is likely that multiple neurotransmitter systems are affected. Therefore, it is still unclear how alcohol, barbiturates, and BDZ are functionally associated with the GABA system.

This proceeding will focus on evidence as to how the GABA system is involved in barbiturate action and the development of tolerance to and physical dependence on barbiturates.

\section{SUMMARY OF GABA SYSTEM AND GABA RECEPTORS}

Gamma-aminobutyric acid (GABA) is one of the major inhibitory neurotransmitters in the mammalian CNS (Krnjevic et al., 1966). Nerve terminals containing binding sites $\left[{ }^{3} \mathrm{H}\right] \mathrm{GABA}$ account for about $30 \%$ of rat cerebral cortex synaptic terminals (Bloom and Iversen, 1971). Although ubiquitous, it was not until 1950 that GABA was identified in the mammalian brain (Awapara et al., 1950; Roberts and Frankel, 1950). Neurons that synthesize GABA are termed "GABA neurons" or "GABAergic neurons"

There are at least two types of GABA receptors in the mammalian brain, $G_{A B A}$ and $\mathrm{GABA}_{\mathrm{B}}$ receptors. The GABA $\mathrm{A}_{\mathrm{B}}$ receptors (Bowe- 
ry et al., 1980) appear to be distinct from the $\mathrm{GABA}_{\mathrm{A}}$ receptors not only in their pharmacological profiles but also in anatomical distribution and sensitivities to ions and guanyl nucleotides ( Matsumoto, 1989). The $\mathrm{GABA}_{\mathrm{A}}$ receptors are ligand-gated chloride channels containing binding sites for GABA and other pharmacologically significant agents, e.g. anxiolytic BDZ (Haefely, 1990), anxiogenic $\beta$-carbolines, hypnotic and anti-convulsant barbiturates (Trifiletti et al., 1985), picrotoxin, t-butyl bicyclophosphorothionate (TBPS) (Squires et al., 1983), and steroid hormones (Im et al., 1990). All these binding sites interact allosterically with each other. Althoug some synaptic reponses mediated by the $\mathrm{GABA}_{\mathrm{A}}$ receptors can be excitatory (Michelson and Wong, 1991), especially in early postnatal hippocampal neurons (Cherubini et al., 1991), the major outcome after binding of GABA or other agonists to the GABA receptors is the opening of chloride ionophores, which allows an inward flow of chloride ions into the cell and results in membrane hyperpolarization as well as reduced neuronal excitability. Binding of $\mathrm{GABA}_{\mathrm{A}}$ antagonists, on the other hand, leads to blockade or reduction of chloride conductance. A rare third class of GABA binding site in the cerebellum, tentatively termed " $\mathrm{GABA}_{\mathrm{C}}$ ", is stimulated by GABA but is insensitive to either bicuculline, a $G_{A B A}$ site antagonist, or $(-)$ baclofen, a $\mathrm{GABA}_{\mathrm{B}}$ site agonist (Drew et al., 1984).

The mechanism and sites of action of some $\mathrm{GABA}_{A}$ agonists and antagonists on the $\mathrm{GABA}_{A}$ receptors are not exactly the same. For example, agonists such as barbiturates prolong the opening state of the chloride channels, while BDZ increase the frequency of chloride channel openings (Study and Barker, 1981). Antagonists such as bicuculline reduce chloride current by competing with GABA, while picrotoxin acts directly at the chloride channel to promote its closure (Simmonds, 1980; Akaike et al., 1985).

The $\mathrm{GABA}_{\mathrm{A}}$ receptor complex is a heterooligomeric protein composed of several distinct polypeptides. At least 5 types of $\mathrm{GABA}_{\mathrm{A}}$ rece- ptor subunit exist, $\alpha, \beta, \gamma, \delta$, and $\rho$. Several lines of evidence indicate that the $\mathrm{GABA}_{A}$ receptors are highly heterogeneous not only in terms of anatomical structure but also pharmacological profiles.

Biochemical studies have provided evidence that there are at least 2 different conformations of $G_{A B A}$ receptor. The high affinity $G_{A B A}$ sites can be labeled with $\left[{ }^{3} \mathrm{H}\right]$ muscimol and are associated with the GABA recognition sites. The low affinity GABA sites, on the other hand, are labeled with $\left[{ }^{3} \mathrm{H}\right]$ bicuculline methochloride and are associated with the $\mathrm{BDZ}$ recognition sites (McCabe and Wamsley, 1986). In addition, the $\mathrm{GABA}_{A}$ receptor protein has been purified to apparent homogeneity using BDZ affinity chromatography, showing a heterologous transmembrane glycoprotein consisting of two subunits, $\mathrm{Mr}$ 50,000 53,000 ( $\alpha$ - subunit) and $\mathrm{Mr}$ $55,000 \sim 57,000$ ( $\beta$-subunit) (Sigel et al., 1983). [ ${ }^{3}$ H] Muscimol photoaffinity labeling also revealed that the GABA recognition site is located on the $\beta$-subunit (Casalotti et al., 1986), while $\left[{ }^{3} \mathrm{H}\right]$ flunitrazepam photoaffinity labeling indicated that the BDZ site is located mainly on the $\alpha$-subunit (Fuchs et al., 1988) or on both the $\alpha$ - and $\beta$-subunit (Bureau and Olsen, 1988). Further GABA receptor heterogeneity was revealed by higher resolution SDS-polyacrylamide gel electrophoresis, showing that each $\alpha$ - and $\beta$-subunit protein band consists of several different proteins (Fuchs et al., 1988). In addition, heterogeneous receptors exist in different brain regions since $\left[{ }^{3} \mathrm{H}\right]$ flunitrazepam photolabeling reveals predominantly 1 protein $(\mathrm{Mr}=51,000)$ in membranes from the cerebellum, while at least 4 proteins $(\mathrm{Mr}=51,000,53,000,55,000$ and 59, 000) are labeled in the hippocampus (Sieghart and Karobath, 1980). Another approach using polyclonal antibodies raised against specific sequence of $\alpha$-subunits has demonstrated the existence of $\mathrm{GABA}_{\mathrm{A}}$ receptor $\alpha$-subunit iso-oligomers (Duggan and Stephenson, 1990).

GABA $_{A}$ receptor-associated BDZ binding sites can be divided into two types, type I (high affinity) or $\mathrm{BZ}_{1}$, and type II (low affinity) or $\mathrm{BZ}_{2}$, 
depending on their affinity toward compounds such as CL 218,872 3-methyl-6[3(triflouromethyl )phenyl]-1,2,4-triazolo[4,3-b]pyridazine) (Squires et al., 1979), and methyl ( $\beta$-CCM), ethyl- $(\beta$ CCE) and propyl- ( $\beta$-CCP) esters of $\beta$-carboline3-carboxylate (Braestrup and Nielsen, 1981; NieIsen and Braestrup, 1980). This diversity in BDZ pharmacology is generated by heterogeneity of the $\alpha$-subunit of the GABA $A$ receptors (Pritchett et al., 1989a). In addition, these two types of $\mathrm{BDZ}$ recepors are not distributed evenly throughout the brain; the cerebellum consists almost exclusively of type I, while the cerebral cortex and the hippocampus consist of both types.

In the cerebellum, two distinct $\mathrm{BDZ}$ binding sites can be bound by Ro. 15-4513 (ethyl- 8 -azido-5, 6-dihydro-5-methyl-6-oxo-4H-imidazo[1 ,5-a][1,4]benzodiazepine- 3-carboxylate), a partial inverse agonist of the central $\mathrm{BDZ}$ receptors. Of these, binding to the diazepam-sensitive (DZ-S) site is displaced by other BDZ receptor ligands, whereas binding to the diazepam-insensitive (DZ -IS) site is not displaceable (Malminiemi and Korpi, 1989). Recently, three different BDZ receptor subtypes were defined according to their high, low, or very low affinity for zolpidem, a non-BDZ imidazopyridine, in several brain regions of the rat (Ruano et al., 1992). These results provide pharmacological evidence of GA$\mathrm{BA}_{\mathrm{A}}$ receptor heterogeneity.

The fast development of molecular cloning and gene expression techniques has speeded up the investigation of the heterogeneity of $\mathrm{GABA}_{A}$ receptors. The cloned cDNAs encoding both the $\alpha$ - and $\beta$-subunits have been prepared using probes based on purified GABA receptors (Schofield et al., 1987), confirming the existence of distinct $\alpha$ - and $\beta$ - subunits of $\mathrm{GABA}_{\mathrm{A}}$ receptor that presumably has a subunit structure of $\alpha_{2} \beta_{2}$. The $\alpha$-subunit and $\beta$-subunit mRNAs, when individually expressed (Blair et al., 1988) or co-expressed (pritchett et al., 1988) in Xenopus oocytes or cultured mammalian cells, produced fully functional receptors and ionophores with the pharmacological profiles characteristic of the
$\mathrm{GABA}_{\mathrm{A}}$ receptors. More recently, it has been found that $\alpha$ - and $\beta$-subunits may exhibit most, but not all, of the native properties of $\mathrm{GABA}_{\mathrm{A}}$ receptors. The $\gamma_{2-}$ (Pritchett et al., 1989b) and $\gamma$ 3- (Knoflach et al., 1991) subunits are believed to be involved in BDZ pharmacology since the BDZ site becomes fully functional only when the cDNAs coding for the human $\alpha_{1}$ and $\beta_{1-}$ subunits are co-expressed with the cDNA coding for the human $\gamma_{2}$-subunit (Pritchett et al., 1989b)

These receptors, however, lack the cooperativity of $\mathrm{GAB}_{\mathrm{A}}$ in gating the chloride channels, and the mRNAs of the $\alpha_{1^{-}}, \beta_{1^{-}}$, and $\gamma_{2}$-subunits are not co-localized in all regions (Mohler et al., 1990 ), pointing to a further diversity of the GABAreceptors.

Further evidence on $\mathrm{GABA}_{\mathrm{A}}$ receptor subunit diversity withir each subunit has been revealed by molecular cloning. Genes coding for multiple $\mathrm{GABA}_{\mathrm{A}}$ receptor subunits has also been isolated. These include: $\alpha_{2^{-}}, \alpha_{3-}$ (Levitan et al., 1988), showing $75 \%$ identity with the previously cloned $\alpha$-subunit, termed $\alpha_{1}$ (Schofield et al., 1987), and $35 \%$ identity with the $\beta$-subunits, $\alpha_{4^{-}}$(Ymer et al., 1989a), $\alpha_{5^{-}}$(Malherbe et al., 1990 ), and $\alpha_{6^{-}}$(Luddens et al., 1990); $\beta_{1^{-}}, \beta_{2^{-}}$, and $\beta_{3-}$ (Ymer et al., 1989b); $\gamma_{1}-($ Ymer et al., 1990), $\gamma_{2}$-(Pritchett et al., 1989b), and $\gamma_{3^{-}}$(Wilson-Shaw et al., 1991); $\delta$ - (Shivers et al., 1989); $\rho_{1}$-and $\rho_{2}$-subunits (Cutting et al., 1991, 1992), two recently cloned subtypes mainly expressed in the retina. Based on the fact the highly variable $\mathrm{GABA}_{A}$ receptor subunits exist in the CNS , it is reasonable to presume that different subunit compositions form the basis for functionally different $\mathrm{GABA}_{\mathrm{A}}$ receptors and different pharmacological responsiveness. Indeed, functional expression of different subunit mRNA combinations co-injected into Xenopus oocytes or co-expression of cDNA in different human cell lines (Pritchett et al., 1989a; Verdoorn et al., 1990) has confirmed that subunit variants provide the structural basis for functionally different $\mathrm{GABA}_{\mathrm{A}}$ receptors. The finding that the GA$\mathrm{BA}_{\mathrm{A}}$ receptor $\alpha_{5}$-subunit is involved in novel type II BDZ receptor pharmacology (Pritchett and 
Seeburg, 1990) is consistent with this notion. In addition, Northern blot analysis and in situ hybridization of mRNAs coding for different GA$\mathrm{BA}_{\mathrm{A}}$ receptor subunits further confirmed the regional and developmental expression of different $\mathrm{GABA}_{\mathrm{A}}$ receptor subunits (Lolait et al., 1989). Some of these results are consistent with those of receptor binding assays. For example, the $\delta$ mRNA distribution is similar to that labeled with [ $\left.{ }^{3} \mathrm{H}\right]$ muscimol, while $\gamma_{2}$-subunit mRNA distribution resembles that labeled with $\left[{ }^{3} \mathrm{H}\right]$ flunitrazepam (Shivers et al., 1989). Thus, the expression of $\mathrm{GABA}_{\mathrm{A}}$ receptor subunits in a regional-specific manner may determine the pharmacological profile of the $G_{A B A}$ receptors in a given brain area. This is supported by the finding that the unique subunit composition of the cerebellar cell layer (Shivers et al., 1989) may be responsible for its unique $\left[{ }^{35} \mathrm{~S}\right] \mathrm{TBPS}$ binding (Korpi et al., 1992). Furthermore, GABA $A_{A}$ receptor subunit assembly has been shown to determine neuronal sorting and localization (Perez-Velazquez and Angelides, 1993), suggesting differential targets for pharmacological modulators.

Recently, Endo and Olsen (1993) demonstrated the brain regional heterogeneity of GA$\mathrm{BA}_{\mathrm{A}}$ receptor $\alpha_{1}-\alpha_{4}$ subunit polypeptides by antisera. The cerebral cortex contained all 4 polypeptides, while hippocampus lacked $\alpha_{3}$ and cerebellum contained only $\alpha_{1}$. Thus, the heterogeneity of the $\mathrm{GABA}_{\mathrm{A}}$ receptor occurs not only at the transcriptional but also in the translational level. Another possible source of $\mathrm{GABA}_{\mathrm{A}}$ receptor heterogeneity comes from the existence of alternatively spliced forms of $\mathrm{GABA}_{\mathrm{A}}$ receptor $\gamma$ - (Kofuji et al., 1991; Whiting et al., 1990) and $\beta$-subunit (Bateson et al., 1991) mRNAs. The two $\gamma_{2}$ forms are termed $\gamma_{2 L}$ and $\gamma_{2 S}$, depending on the presence or absence of a 24-base-pair (8amino acid) insertion in the cytoplasmic domain between $\mathrm{M}_{3}$ and $\mathrm{M}_{4}$ transmembrane regions. Further, the insertion $\left(\gamma_{2 \mathrm{~L}}\right)$ creates a protein kinase $\mathrm{C}$ consensus phosphorylation site, indicating differential regulation of the $\mathrm{GABA}_{\mathrm{A}}$ receptor subunit function.
In summary, the $\mathrm{GABA}_{A}$ receptor consists of at least five different but homologous subunits, and each subunit exists as a family of subtypes with similar but distinct gene sequence. The subunit variations contribute, at least in part, to the pharmacological heterogeneity of $\mathrm{GABA}_{\mathrm{A}}$ receptors in different brain areas.

\section{EFFECTS OF PENTOBARBITAL ON THE GABA RECEPTORS}

Barbiturates are agents widely used clinically as sedatives, anticonvulsants, and anesthetics. One of the short- to intermediate-acting barbiturates, pentobarbital, a synthetic racemic compound, is used in clinical medicine for its ability to induce a general anesthetic state. The $(-)$ isomer is more potent than the $(+)$ isomer in augmenting the chloride ion current (Huang and Barker, 1980) as well as inducing anesthesia (Waddell and Baggett, 1973). As CNS depressants, barbiturates can have many effects on the nervous system (Ho and Harris, 1981), including effects on the excitatory amino acid receptors (Cai and McCaslin, 1993; Short and Tabakoff, 1993). Even the specific strong hydrogen bonding of barbiturates with derivatives of adenine was once considered a basis for interpreting their mode of action (Kyogoku et al., 1968). This is because of the extremely diverse action of barbiturates and of the widespread existence of adenine derivatives, including ATP and coenzymes, in the cell (Kyogoku et al., 1968). The GABA synapse, however, may be their major target in inducing their therapeutic effects as well as tolerance and dependence (Ho, 1980; Saunders and Ho,1990). Pentobarbital-induced hypnosis, for example, involves $\mathrm{GABA}_{\mathrm{A}}$ receptor function (Chweh et al., 1987). Additionally, a variety of neurochemical studies have indicated that barbiturates interact with the postsynaptic $\mathrm{GABA}_{\mathrm{A}}$ receptor in a direct way, which at the tissue, cellular, and molecular level correlates well with their anesthetic activity (Olsen, 1981). Studies on effects of barbiturates on the $\mathrm{GABA}_{A}$ receptors are available in the literature. These 
can be categorized under their effects on ${ }^{36} \mathrm{Cl}$ flux, and in vitro and in vivo (acute and chronic ) effects on the GABA $A$ receptors.

Numerous in vitro electrophysiological studies have shown that pentobarbital potentiates the $\mathrm{GABA}_{\mathrm{A}}$ receptor-mediated inhibition (Akaike et al., 1987; Barker and Ransom, 1978; Nicoll and Wojtowicz, 1980), i.e. GABA A receptor -coupled chloride channel opening and postsynaptic inhibitory potential. In addition, the GA$\mathrm{BA}_{\mathrm{A}}$ antagonist picrotoxin, which blocks the chloride channel, can reverse this pentobarbitalinduced hyperpolarization (Nicoll, 1975), further indicating that the action of pentobarbital is mediated through the activation of $\mathrm{GABA}_{A}$ receptors. Other studies on ${ }^{36} \mathrm{Cl}$ - efflux measured from brain slices (Wong et al., .1984) also confirmed that pentobarbital produces a dose-dependent activation of ${ }^{36} \mathrm{Cl}-$ efflux with a maximal response greater than that of GABA, and that the action of GABA is potentiated by pentobarbital. Measurement of ${ }^{36} \mathrm{Cl}$ - uptake in rat cerebral cortical synaptoneurosomes (Schwartz et al., 1986) and microsacs (Allan and Harris, 1986), however, showed that pentobarbital stimulates ${ }^{36} \mathrm{Cl}$ - uptake in a biphasic manner with higher concentrations of pentobarbital stimulates ${ }^{36} \mathrm{Cl}-$ uptake, indicating that the desensitization of $\mathrm{GABA} / \mathrm{Cl}$ - ionophores may involve the barbiturate recognition sites.

In vitro binding studies contribute further to the understanding of the mechanism of action of pentobarbital on the $\mathrm{GABA}_{\mathrm{A}}$ receptors. Pentobarbital allosterically enhances the chloride -dependent $\left[{ }^{3} \mathrm{H}\right]$ muscimol (Supavilai et al., 1982) and $\left[{ }^{3} \mathrm{H}\right] \mathrm{GABA}$ (Asano and Ogasawara, 1981) binding to the $\mathrm{GABA}_{\mathrm{A}}$ receptors. This enhancement is concentration-dependent and varies with brain regions in a way that does not correlate well with the overall GABA receptor binding. For instance, the cerebellum displays poor barbiturate enhancement despite a high level of GABA binding (Olsen and Snowman, 1982). In addition, both the basal $\left[{ }^{3} \mathrm{H}\right]$ diazepam and GABA-enhanced $\left[{ }^{3} \mathrm{H}\right]$ diazepam binding are potentiated by pentobarbital through an increase in affinity of the $\mathrm{BDZ}$ receptors for diazepam (Skolnick et al., 1981). Binding of the cage convulsant, $\left[{ }^{35} \mathrm{~S}\right] \mathrm{TBPS}$, on the other hand, is not only brain area-dependent but also salt-dependent. A biphasic effect (stimulation at lower concentration followed by inhibition at higher concentration of $\left[{ }^{35} \mathrm{~S}\right] \mathrm{TBPS}$ binding is produced by pentobarbital in the cortex, while only inhibition is observed in the cerebellum (Liljequist and Tabakoff, 1986). The presence of specific salts in the assay medium seems critical for these binding assays. Biphasic modulation of $\left[{ }^{35} \mathrm{~S}\right] \mathrm{TBPS}$ binding by pentobarbital, which correlates perfectly with the results of ${ }^{36} \mathrm{Cl}$ - uptake, can only be seen when the assay medium contains $\mathrm{KCl}$ or $\mathrm{NaCl}$ (Liljequist and Tabakoff, 1986; Supavilai and Karobath, 1984). In other studies done in medium containing $\mathrm{KBr}$ or $\mathrm{NaBr}$, pentobarbital produces only inhibition of $\left[{ }^{35} \mathrm{~S}\right]$ TBPS binding ( Ramanjaneyulu and Ticku, 1984; Supavilai and Karobath, 1984; Squires et al., 1983).

Acute exposure to pentobarbital has been shown to increase and decrease, respectively, the brain levels of GABA and glutamate (Tzeng and Ho, 1977), which is associated with pentobarbital-induced narcosis. Changes of specific GA$\mathrm{BA}_{\mathrm{A}}$ receptor recognition sites were also observed - Acute pentobarbital increased the whole brain $\left[{ }^{3} \mathrm{H}\right]$ muscimol bindings due to increased receptor numbers rather than a change in the apparent affinity (Sivam et al., 1982). Similar results were seen in an in vivo BDZ receptor binding study, which showed increased BDZ binding in several brain areas following acute pentobarbital exposure as assessed by the specific uptake of $\left[{ }^{3} \mathrm{H}\right] \mathrm{Ro}$ 15-1788 (ethyl-8-fluoro-5, 6-dihydro-5-methyl6 - oxo-4H-imidazol $[1,5 \mathrm{a}][1,4]$ benzodiazepine-3carboxylate)(Miller et al., 1988). Tatsuoka et al. (1984) demonstrated a region-specific effect of acute phenobarbital on $\left[{ }^{3} \mathrm{H}\right] \mathrm{GABA}$ binding. $\left[{ }^{35} \mathrm{~S}\right]$ TBPS binding, on the other hand, is not affected by acute pentobarbital treatment (Ito et al., 1989). In general, the acute effects of pentobarbital on the $\mathrm{GABA}_{A}$ receptor complexes correlate relatively well with those seen in vitro and are freely reversible (Saunders and Ho, 
1990).

In contrast to acute exposure, chronic administration of pentobarbital decreased the brain levels of both GABA and glutamate, with GABA levels remaining low even after an abrupt withdrawal from pentobarbital (Tzeng and Ho, 1977), indicating a possible linkage between inhibition of GABA synapses and dependence on pentobarbital. A further decrease of GABA levels in animals rendered dependent upon pentobarbital was observed after convulsions induced by pentylenetetrazole (PTZ) (Ho et al., 1979), a compound similar to picrotoxin in blocking the GABA receptor chloride channels (Pellmar and Wilson, 1977), suggesting the associ- ation of reduced brain GABA levels and PTZinduced convulsive responses in pentobarbital dependent animals. In terms of receptor binding, chronic pentobarbital treatment increased the whole brain $\left[{ }^{3} \mathrm{H}\right]$ muscimol binding to synaptic membranes due to an increase in $B_{\max }$ instead of an alteration in $K_{D}$, consistent with results of acute treatment. Furthermore, abrupt withdrawal from chronic pentobarbital can reverse this increase in receptor population (Sivam et al., 1982). Gray and Taberner (1985), in contrast, demonstrated that the $\mathrm{K}_{\mathrm{D}}$ for the high affinity [ ${ }^{3}$ H]GABA binding site is significantly increased in barbital-withdrawn mice. Studies done in isolated chick embryo neurons grown in primary

Table 1. Summary of changes in $\mathrm{GABA}_{A}$ receptor binding characteristics in pentobarbital-tolerant and withdrawn animals

\begin{tabular}{llll}
\hline Tolerance & GABA site & $\mathrm{BDZ}$ site & Convulsant site \\
\hline Whole brain & $0 \mathrm{~K}_{\mathrm{D}} \uparrow \mathrm{Bmax}^{7}$ & $\downarrow \mathrm{K}_{\mathrm{D}}, \mathrm{Bmax}^{9}$ & \\
Cortex & $0^{4,10}$ & 0 & $0^{4,5}$ \\
Cerebellum & $\mathrm{K}_{\mathrm{DL}}(\text { antagonist })^{7}$ & $\downarrow \mathrm{Bmax}\left(\mathrm{BZ}_{2}\right)$ & \\
& 0 (antagonist $^{7}$ & $0 \mathrm{Bmax}^{4}$ & $0 \mathrm{~K}_{\mathrm{D}}, \uparrow \mathrm{Bmax}^{2}$ \\
Striatum & $\uparrow \mathrm{Bmax}^{4}$ & $0 \mathrm{Bmax}^{4}$ & 0 \\
Sub. nigra & & & $0^{2}$ \\
\hline
\end{tabular}

Withdrawal

\begin{tabular}{|c|c|c|c|}
\hline Whole brain & $\begin{array}{l}0 \mathrm{~K}_{\mathrm{D}}, \uparrow \mathrm{Bmax}_{\mathrm{H}}{ }^{1} \\
0 \mathrm{Bmax}(72-\mathrm{hr})^{8} \\
\uparrow \mathrm{Bmax}(24-\mathrm{hr})^{8}\end{array}$ & & \\
\hline Cortex & $\begin{array}{l}\uparrow \mathrm{K}_{\mathrm{DL}}^{6} \\
\downarrow \mathrm{Bmax} \text { (Antagonist) }\end{array}$ & $0 \mathrm{~K}_{\mathrm{D}}, \uparrow \mathrm{Bmax} 5$ & $0 \mathrm{~K}_{\mathrm{D}} \uparrow \mathrm{Bma}^{2,7}$ \\
\hline $\begin{array}{l}\text { Cerebellum } \\
\text { Striatum } \\
\text { Sub. nigra }\end{array}$ & $0{\text { (antagonist })^{7}}^{7}$ & & $\begin{array}{l}0 \mathrm{~K}_{\mathrm{D}}, \uparrow \mathrm{Bmax}^{2} \\
0 \mathrm{~K}_{\mathrm{D}}, \uparrow \mathrm{Bmax}^{2} \\
0 \mathrm{~K}_{\mathrm{D}}, \uparrow \mathrm{Bmax}^{2}\end{array}$ \\
\hline
\end{tabular}

$\uparrow$, increase; $\downarrow$, decrease; 0 , no change.

$\mathrm{K}_{\mathrm{D}}$, equilibrium dissociation constant; $\mathrm{K}_{\mathrm{DH}}, \mathrm{K}_{\mathrm{D}}$ for high affinity sites; $\mathrm{K}_{\mathrm{DL}}, \mathrm{K}_{\mathrm{D}}$ for low affinity sites; Bmax, maximal receptor density; BmaxH, Bmax for high affinity sites; $\mathrm{B}_{\operatorname{maxL}}, \mathrm{Bmax}$ for low affinity sites.

References: 1. Gray and Taberber, 1985; 2. Ito et al., 1989; 3. Liljequist and Tabakoff, 1985; 4. Mohler et al., 1978; 5. Miyaoka et al., 1994; 6. Nordberg et al., 1986; 7. Saunders et al., 1992; 8. Sivam et al., 1982; 9. Sonowane et al., 1980; 10. Tatsuoka et al., 1984. 
culture exposed to chronic pentobarbital showed that the GABA and pentobarbital-enhanced $\left[{ }^{3} \mathrm{H}\right]$ diazepam (Roth-Schechter et al., 1983) and barbital-enhanced $\left[{ }^{3} \mathrm{H}\right]$ flunitrazepam binding (Roca et al., 1990) were reduced significantly. Thus, chronic pentobarbital treatment not only affects the sensitivity of the $\mathrm{GABA}_{\mathrm{A}}$ receptor complexes to barbiturate but also to GABA. This suggests the abolishment of allosteric coupling between the BDZ and barbiturate sites following chronic pentobarbital exposure.

Relatively few studies have been done on the effects of tolerance to and dependence upon pentobarbital on $\mathrm{BDZ}$ receptor binding characteristics. Miyaoka et al. (1994) observed on changes in $\left[{ }^{3} \mathrm{H}\right]$ flunitrazepam binding even after 6 days of i.c.v. (intracerebroventricular) pentobarbital infusion. Twenty-four hours following abrupt withdrawal, however, an increase in $\mathbf{B}_{\max }$ with no changes in apparent affinity was observed. On the other hand, the binding characteristics of the BDZ antagonist $\left[{ }^{3} \mathrm{H}\right]$ Ro151788 were not affected by pentobarbital withdrawal. These results suggest possible conformational changes in the $\mathrm{BDZ}$ erceptor caused by abrupt withdrawal following chronic pentobarbital treatment. Another chronic study using phenobarbital (Liljequist and Tabakoff. 1985) showed reduced type I and type II BDZ binding in the cerebellum and cortex, respectively. $\left[{ }^{35} \mathrm{~S}\right] \mathrm{TBPS}$ binding characteristics in most of the brain areas of chronic pentobarbital-treated rats are not changed except in cerebellum, where an increased density of $\left[{ }^{35} \mathrm{~S}\right] \mathrm{TBPS}$ binding sites with no changes in their apparent affinity is observed (Ito et al., 1989). Following development of dependence upon pentobarbital, increases in the density of $\left[{ }^{35} \mathrm{~S}\right] \mathrm{TBPS}$ binding sites, which correlate well with the changes in sensitivities to seizure, were seen in the frontal cortex, substantia nigra, and cerebellum, but not in the striatum (Ito et al., 1989). The effects of chronic administration of barbiturate on different GA$\mathrm{BA}_{\mathrm{A}}$ receptor recognition sites in different brain regions, in terms of changes in binding characteristics, are summarized in table 1.
In summary, although controversial results exist concerning the effects of tolerance to and dependence upon pentobarbital on the different $\mathrm{GABA}_{\mathrm{A}}$ receptor recognition sites, it seems that dependence upon pentobarbital can cause some changes, either functional or conformational, on this receptor complex that result in alterations of receptor binding characteristics.

\section{FUTURE STUDIES}

The immediate goal should be to investigate the funtional importance of postsynaptic GABA $_{A}$ receptors in the processes of development of tolerance to and physical dependence upon pentobarbital. Based on the evidence available, it is hypothesized that, similar to the in vitro condition, pentobarbital facilitates $\mathrm{Cl}$ - influx by interacting with barbiturate/convulsant sites of $\mathrm{GABA}_{A}$ receptors. This interaction allosterically facilitates binding of GABA and BDZ to their respective sites. The $G_{A B A}$ receptors are desensitized (down regulated) during the process of tolerance development. In the withdrawal state, the desensitized/down-regulated receptors become hyposensitive to agonists of the GABA-, BDZ- and barbiturate-binding sites, or become supersensitive to antagonists of the GABA and BDZ sites and to convulsants. The functional chages in $\mathrm{GABA}_{\mathrm{A}}$ receptors during the development of pentobarbital tolerance and dependence may be due to characteristic alterations of different binding sites of the complex. Due to heterogeneity of the $\mathrm{GABA}_{\mathrm{A}}$ receptors, it is further hypothesized that $\mathrm{GABA}_{A}$ receptors in different regions of the CNS are affected differently by pentobarbital.

Systematic investigations of the role of GA$\mathrm{BA}_{\mathrm{A}}$ receptors in pentobarbital tolerance-dependence are possible by mapping out the localization and specificity of pentobarbital effects on different subtypes of $\mathrm{GABA}_{\mathrm{A}}$ receptors. This can be achieved by biochemical radioligand binding assays, autoradiography, and in situ hybridization techniques using cDNA probes. Biochemical ligand assays and autoradiography will 
reveal how pentobarbital alters the characteristics (affinity and receptor number) of $\mathrm{GABA}_{\mathrm{A}}$ receptors. Autoradiographic studies will further define changes in $G_{A B A}$ receptors in smaller areas (e.g. globus pallidus, dentate gyrus, substantia nigra, etc.) or different locations of brain regions (e.g. molecular layer and granule layer of cerebellun). The in situ hybridization studies will advance the understanding of in vivo effects of pentobarbital on expression of different subunits of $\mathrm{GABA}_{\mathrm{A}}$ receptors in different regions of the CNS. The studies shall be further complimented by investigating physiological functions $\mathrm{GABA}_{\mathrm{A}}$ receptor-mediated $\mathrm{C} 1$-flux.

\section{ACKNOWLEDGEMENTS}

This work was supported by a grant DA 04480 from National Institute on Drug Abuse.

\section{REFERENCES}

1. Akaike, N., K. Hattori, Y. Oomura and D. O. Carpenter. 1985. Bicuculline and picrotoxin block $\gamma$-aminobutyric acid-gated $\mathrm{Cl}$ - conductance by different mechanisms. Experientia. $41: 70-71$.

2. Akaike, N., T. Maruyama and N. Tokutomi. 1987. Kinetic properties of the pentobarbitone-gated chloride current in frog sensory neurones. J. Physiol. 394 : 85-98.

3.Allan, A. M. and R.A.Harris. 1986. Anesthetic and convulsant barbiturates alter $\gamma$ aminobutyric acid-stimulated chloride flux across brain membranes. J. Pharmacol. Exp. Ther. $238:$ 763-768.

4. Asano, T. and N. Ogasawara. 1981. Chloride -dependent stimulation of GABA and benzodiazepine receptor binding by pentobarbital. Brain Res. 225 : 212-216.

5. Awapara, J., A. J. Landua, R. Fuerst and B. Seale. 1950. Free $\gamma$-aminobutyric acid in brain. J. Biol. Chem. $187:$ 35-39.

6. Barker. J. L. and B. R. Ransom. 1978. Pentobarbitone pharmacology of mammalian central neurons grown in tissue culture. J. Physiol. $280: 355-372$.

7. Bateson, A. N., A. Lasham and M. G. Darlison. 1991. $\gamma$-Aminobutyric $\operatorname{acid}_{A}$ receptor heterogeneity is increased by alternative splicing of a novel $\beta$-subunit gene transcript. $\mathbf{J}$. Neurochem. $56: 1437-1440$

8. Blair, L. A. C., E. S. Levitan, J. Marshall, V. E. Dionne and E. A. Barnard. 1988. Single subunits of the $\mathrm{GABA}_{\mathrm{A}}$ receptor form ion channels with properties of the native receptor. Science. $242: 577-579$.

9. Bloom, F. E. and L. L. Iversen. 1971. Localizing ${ }^{3} \mathrm{H}$-GABA in nerve terminals of rat cerebral cortex by electron microscopic autoradiography. Nature. $299:$ 628-630.

10. Bowery, N. G., A. Doble, D. R. Hill, A. L. Hudson, D. N. Middlemiss, J. Shaw and M. Turnbull. 1980. (-) Baclofen decreases neurotransmitter release in the mammalian $\mathrm{CNS}$ by an action at a novel GABA receptor. Nature. $283: 92-94$.

11. Braestrup, C. and M. Nielsen. 1981. $\left[{ }^{3} \mathrm{H}\right]$ Propyl $\beta$-carboline-3-carboxylate as a selective radioligand for $\mathrm{BZ}_{1}$ benzodiazepine receptor subclass. J. Neurochem. 37 : 333-341.

12. Burean, M. and R. W. Olsen. 1988. $\gamma$ Aminobutyric acid/benzodiazepine receptor protein carries binding sites for both ligands on both two major peptide subunits. Biochem Biophys. Res. Comm. 153 : 1006-1011.

13. Cai, Z. and P. P. McCaslin. 1993. Acute, chronic and differential effects of several anesthetic barbiturates on giutamate receptor activation in neuronal culture. Brain Res. 611: 181-186.

14. Casalotti, S. O., F.A. Stephenson and E.A. Barnard. 1986. Separate subunits for agonist and benzodiazepine binding in the $\gamma$-amino butyric $\operatorname{acid}_{A}$ receptor oligomer. J. Biol., Chem. 261 : 15013-15016.

15. Cherubini, E., J. L. Gaiarsa and Y. Ben-Ari. 1991. GABA: an excitatory transmitter in early postnatal life. Trends in Neurosci. 14 : 511-519.

16. Chweh. A. Y., E. A. Swinyard and H. H. 
Wolf. 1987. Hypnotic action of pentobarbital in mice : a possible mechanism. Exp. Neurol. $97: 70-76$.

17. Cutting, G. R., S. Curristin, H. Zoghbi, B. O'Hara, M.F. Seldin and G.R. Uhl. 1992. Identification of a putative $\gamma$-aminobutyric acid (GABA) subunit rho 2 cDNA and colocalization of the genes encoding $\mathrm{rho}_{2}$ (GABRR2) and rho, (GABRR1) to human chromosome 6q14-q21 and mouse chromosome 4. Genomics. 12 : 801-806.

18. Cutting, G. R., L. Lu, B. F. O' Hara, L. M. Kasch, C. Montrose-Rafizadeh, D. M. Donovan, S. Shimada, S. E. Antonarakis, W. B. Guggino, G. R. Uhl and H. H. Kazazian Jr. 1991. Cloning of the $\gamma$-aminobutyric acid (GABA) $\rho_{1}$ cDNA: a GABA receptor subunit highly expressed in the retina. Proc. Natl. Acad. Sci. USA. 88 : 2673-2677.

19. Drew, C. A., G. A. R. Johnston and R. P. Weatherby. 1984. Bicuculline-insensitive GABA receptors: studies on the binding of (-)-baclofen to rat cerebellar membranes. Neurosci. Lett. 52 :317-321.

20. Duggan, M. J. and F. A. Stephenson. 1990. Biochemical evidence for the existence of $\gamma$

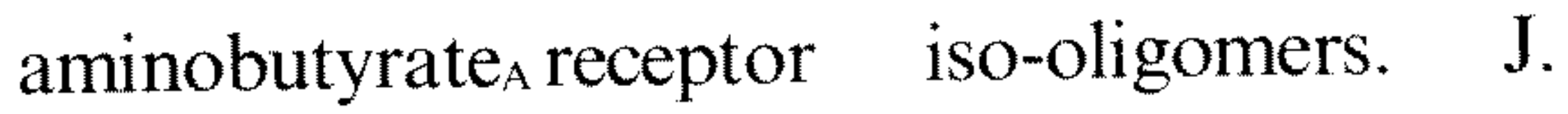
Biol. Chem. $265:$ 3831-3835.

21. Endo, S. and R. W. Olsen. 1993. Antibodies specific for $\alpha$-subunit subtypes of $\mathrm{GABA}_{\mathrm{A}}$ receptors reveal brain regional heterogeneity. $J$. Neurochem. $60: 1388-1398$.

22. Fuchs, K., H. Möhler and W. Sieghart. 1988. Various proteins from rat brain, specifically and irreversiby labeled by $\left[{ }^{3} \mathrm{H}\right]$ flunitrazepam, are distinct $\alpha$-subunits of the GABA-benzodiazepine receptor complex. Neurosci. Lett. $90: 314-319$.

23. Gray, P. L. and P. V. Taberner. 1985. Evidence for GABA tolerance in barbiturate-dependent and withdrawn mice. Neuropharmacology. 24 : 437-444.

24.Haefely, W. 1990. The GABA-benzodiazepine interaction fifteen years later. Neurochem. Res. $15: 169-174$.

25.Ho, I. K. 1980. Effects of acute and chronic administration of pentobarbital on GABA system. Brain Res. Bull. 5 (Suppl. 2) : 913917.

26. Ho, I. K., B. A. Flint and T. Gilliland. 1979. Comparative effect of diazepam and valproate on pentylenetetrazol (PTZ) induced convulsions in pentobarbital dependent mice. Fed. Proc. $38: 434$.

27.Ho, I. K. and R. A. Harris. 1981. Mechanism of action of barbiturates. Ann. Rev. Pharmacol., Toxicol. $21: 83-111$.

28. Huang, L.-Y. M. and J. L. Barker. 1980. Pentobarbital: stereospecific actions of $(+)$ and $(-)$ isomers revealed on cultured mammalian neurons. Science. $207:$ 195-197.

29. Im, W. B., D. P. Blakeman, J. P. Davis and D. E. Ayer. 1990. Studies on the mechanism of interactions between anesthetic steroids and $\gamma$-aminobutyric $\mathrm{acid}_{\mathrm{A}}$ receptors. Mol. Pharmacol. 37 : 429-434.

30. Ito, Y., P. A. Saunders, D. K. Lim and I. K. Ho. 1989. Binding characteristics of $t-\left[{ }^{35} \mathrm{~s}\right]$ butylbicyclophosphorothionate in discrete brain regions of rats made tolerant and dependent on pentobarbital. J. Neurochem. 52 : 1093-1098.

31. Knoflach, F., Th. Rhyner, M. Villa, S. Kellenberger, U. Drescher, P. Malherbe, E. Sigel and H. Mohler. 1991. The $\gamma_{3}$-subunit of the $\mathrm{GABA}_{\mathrm{A}}$-receptor confers sensitivity to benzodiazepine receptor ligands. FEBS Lett. $293: 191-194$

32. Kofuji, P., J. B. Wang, S. J. Moss, R. L. Huganir and D. R. Burt. 1991. Generation of two forms of the $\gamma$-aminobutyric $\operatorname{acid}_{A}$ receptor $\gamma_{2}$-subunit in mice by alternative splicing J. Neurochem. $56:$ 713-715.

33. Korpi, E. R., H. Luddens and P. H. Seeburg. 1992. $\mathrm{GABA}_{\mathrm{A}}$ antagonists reveal binding sites for $\left.{ }^{35} \mathrm{~S}\right] \mathrm{TBPS}$ in cerebellar granular cell layer. Eur. J. Pharmacol. 211 : 427-428.

34. Krnjevic, K., M. Randic and D. W. Straughan. 1966. Pharmacology of cortical inhibition. J. Physiol. 184 : 78-105.

35. Kyogoku, Y., R. C. Lord and A. Rich. 1968. Specific hydrogen bonding of barbiturates to 
adenine derivatives. Nature. $218: 69-72$.

36. Levitan, E. S., P. R. Schofild, D. R. Burt, L. M. Rhee, W. Wisden, M. Köhler, N. Fujita, H. F. Rodriguez, A. Stephenson, M. G. Darlison, E. A. Barnard and P. H. Seeburg. 1988. Structural and functional basis for GA$\mathrm{BA}_{\mathrm{A}}$ receptor heterogeneity. Nature. 335 : 7679.

37.Liljequist, S. and B. Tabakoff. 1986. Bicuculline-pentobarbital interactions on $\left[{ }^{35} \mathrm{~S}\right] \mathrm{TBPS}$ binding in various brain areas. Life Sci. 39 : 851-855.

38. Liljequist. S and B. Tabakoff. 1985. Binding characteristics of ${ }^{3} \mathrm{H}$-flunitrazepam and $\mathrm{CL}$ 218,872 in cerebellum and cortex of C57B1 mice made tolerant to and dependent on phenobarbital or ethanol. Alcohol. 2 : 215220.

39.Lolait, S. J., A.-M. O' Carroll, K. Kusano and L. C. Mahan. 1989. Pharmacological characterization and region-specific expression in brain of the $\beta_{2}$-and $\beta_{3}$-subunits of the rat $\mathrm{GABA}_{\mathrm{A}}$ receptor. FEBS Lett. 258:17-21.

40. Luddens, H., D. B. Pritchett, M. Kohler, I. Killisch, K. Keinanen, H. Monyer, R. Sprengel and P. H. Seeburg. 1990. Cerebellar GA$\mathrm{BA}_{\mathrm{A}}$ receptor selective for a behavioural alcohol antagonist. Nature. $346: 648-651$.

41. Malherbe, P., E. Sigel, R. Baur, E. Persohn, J. G. Richards and H. Mohler. 1990. Functional expression and sites of gene transcription of a novel $\alpha$ subunit of the GABA $\mathrm{A}_{\mathrm{A}}$ receptor in rat brain. FEBS Lett. $260: 261-265$.

42. Malminiemi, O. and E. R. Korpi. 1989. Diazepam-insensitive $\left[{ }^{3} \mathrm{H}\right] \mathrm{Ro}$ 15-451 binding in intact cultured cerebellar granule cells. Eur. J. Pharmacol. $169: 53-60$.

43. Matsumoto, R. R. 1989. GABA receptors: are cellular differeces reflected in function? Brain Res. Rev. 14 : 203-225.

44. McCabe, R. T. and J. K. Wamsley. 1986. Autoradiographic localization of subcomponents of the macromolecular GABA receptor complex. Life Sci. $39: 1937$ - 1945.

45. Michelson, H. B. and R. K. S. Wong. 1991. Excitatory synaptic responses mediated by
$\mathrm{GABA}_{\mathrm{A}}$ receptors in the hippocampus. Science. $253:$ 1420-1423.

46. Miller, L. G., D. J. Greenblatt, J. G. Barnhill and R. I. Shader. 1988. Differential modulation of benzodiazepine receptor binding by ethanol in LS and SS mice. Pharmacol. Biochem. Behav. 29 : 471-477.

47. Miyaoka, T., T. Kimura, P. A. Saunders, Y. T. Tseng and I. K. Ho. 1994. Binding characteristics of $\left[{ }^{3} \mathrm{H}\right]$ flunitrazepam in pentobarbital-withdrawal rats. Neurochem. Res. $19: 37-42$.

48. Möhler, H., P. Malherbe, A. Draguhn and J. G. Richards. 1990. GABA $A_{A}$-receptors: structural requirements and sites of gene expression in mammalian brain. Neurochem. Res. $15: 199-207$.

49. Möhler, H., T. Okada and S. J. Enna. 1978. Benzodiazepine nad neurotransmitter receptor binding in rat brain after chronic administration of diazepam or phenobarbital. Brain Res. 156 : 391-395.

50. Nicoll, R. A. 1975. Pentobarbital : action on frog motoneurons. Brain Res. $96: 119-123$.

51. Nicoll, R. A. and J. M. Wojtowicz. 1980. The effects of pentobarbital and related compounds on frog motoneurons. Brain Res. 191 : 225-237.

52. Nielsen, M. and C. Braestrup. 1980. Ethyl $\beta$ carboline-3-carboxylate shows differential benzodiazepine receptor interaction. Nature. 286: 606-607.

53. Nordberg, A., G. Wahlstrom and B. Eriksson. 1986. $\left[{ }^{3} \mathrm{H}\right]$ Muscimol and $\left[{ }^{3} \mathrm{H}\right]$ quinuclidinyl benzilate binding in rat cortex in the abstinence after long-term barbital treatment. Acta Physiol. Scand. 126 : 153-156.

54. Olsen, R. W. 1981. GABA-benzodiazepinebarbiturate receptor interactions. J. Neurochem. $37: 1-13$.

55. Olsen, R. W. and A. M. Snowman. 1982. Chloride-dependent enhancement by barbiturates of $i$-aminobutyric acid receptor binding. J. Neurosci. 2 : 1812-1823.

56. Pellmar, T. C. and W. A. Wilson. 1977. Synaptic mechanism of pentylenetetrazole: sele- 
ctivity for chloride conductance. Science. 197 : 912-914.

57. Perez-Velazquez, J. L. and K. J. Angelides. 1993. Assembly of $\mathrm{GABA}_{A}$ receptor subunits determines sorting and localization in polarized cells. Nature. 361 : 457-460.

58. Pritchett, D. B., H. Lüddens and P. H. Seeburg. 1989a. Type I and type II GABA $A$-benzodiazepine receptors produced in transfected cells. Science. $245:$ 1389-1392.

59.Pritchett, D. B. and P. H. Seeburg. 1990. $\gamma$ Aminobutyric acid $_{A}$ receptor $\alpha_{5}$-subunit creates novel type II benzodiazepine receptor pharmacology. J. Neurochem. 54 : 1802-1804.

60.Pritchett, D. B., H. Sontheimer, C. M. Gorman, H. Kettenmann, P. H. Seeburg and P. R. Schofield. 1988. Transient expression shows ligand gating and allosteric potentiation of $\mathrm{GABA}_{\mathrm{A}}$ receptor subunits. Science. $242: 1306-1308$.

61.Pritchett, D. B., H. Sontheimer, B. D. Shivers, S. Ymer, H. Kettenmann, P. R. Schofield and P. H. Seeburg, 1989b. Importance of a novel $\mathrm{GABA}_{\mathrm{A}}$ receptor subunit for benzodiazepine pharmacology. Nature. 338 : 582-585.

62. Ramanjaneyulu, R. and M. K. Ticku. 1984. Binding characteristics and interactions of depressant drugs with $\left[{ }^{35} \mathrm{~S}\right]$ t-butylbicyclophosphorothionate, a ligand that binds to the picrotoxinin site. J. Neurochem. 42 : 221-229.

63. Roberts. E. and S. Frankel. 1950. \%Aminobutyric acid in brain : its formation from glutamic acid. J. Biol. Chem. 187 : 5563.

64. Roca, D. J., G. D. Schiller, L. Friedman, I. Rozenberg, T. T. Gibbs and D. H. Farb. 1990. $\gamma$-Aminobutyric acid $_{\mathrm{A}}$ receptor regulation in culture : altered allosteric interactions following prolonged exposure to benzodiazepines, barbiturates, and methylxanthines. Mol. Pharmacol. 37 :710-719.

65. Roth-Schechter, B. F., C. Ebel and P. Mallorga. 1983. Chronic pentobarbital diminishes GABA- and pentobarbital-enhanced $\left[{ }^{3} \mathrm{H}\right]$ dia- zepam binding to benzodiazepine receptors. Eur. J. Pharmacol. 87 : 169-170.

66. Ruano, D., M. Vizuete, J. Cano, A. Machado and J. Vitorica. 1992. Heterogeneity in the allosteric interaction between the $\gamma$ aminobutyric acid (GABA) binding site and three different benzodiazepine binding sites of the $\mathrm{GABA}_{\mathrm{A}}$ /benzodiazepine receptor complex in the rat nervous system. J. Neurochem. $58: 485-493$.

67. Saunders, P. A. and I. K. HO. 1990. Barbiturates and the $\mathrm{GABA}_{\mathrm{A}}$ receptor complex. Prog. Drug Res. 34 : 261-286.

68. Saunders, P. A., T. Kimura, T. Miyaoka and I. K. HO. 1992. Effects of pentobarbital tolerance and dependence on convulsant and $\mathrm{GABA}_{\mathrm{A}}$ receptor antagonist binding. Life Sci. $50: 1701-1709$.

69. Schofield, P. R., M. G. Darlison, N. Fujita, D. R. Burt, F. A. Stephenson, H. Rodriguez, L.M. Rhee, J. Ramachandran, V. Reale, T. A. Glencorse, P. H. Seeburg and E.A. Barnard. 1987. Sequence and functional expression of the $\mathrm{GABA}_{\mathrm{A}}$ receptor shows a ligand-gated receptor superfamily. Nature. 328 : 221-227.

70. Schwartz, R. D., P. D. Suzdak and S. M. Paul. 1986. $\gamma$-Aminobutyric acid (GABA)and barbiturate-mediated ${ }^{36} \mathrm{Cl}$ - uptake in rat brain synaptoneurosomes : evidence for rapid desensitization of the GABA receptorcoupled chloride ion channel. Mol. Pharmacol. $30: 419-426$.

71. Shivers, B. D., I. Killisch, R. Sprengel, H. Sontheimer, M. Köhler, P.R. Schofield and P.H. Seeburg. 1989. Two novel GABA receptor subunits exist in distinct neuronal subpopulations. Neuron, $3: 327-337$.

72. Short, K.R. and B.Tabakoff. 1993. Chronic barbiturate treatment increases NMDA receptors but decreases kainate receptors in mouse cortex. Eur. J. Pharmacol. 230 : 111114.

73. Sieghart, W. and M. Karobath. 1980. Molecular heterogeneity of benzodiazepine receptors. Nature. $286:$ 285-287. 
74. Sigel, E., F. A. Stephenson, C. Mamalaki and E. A. Barnard. 1983. A $\gamma$-aminobutyric acid/benzodiazepine receptor complex of bovine cerebral cortex. J. Biol. Chem. 258 : 6965-6971.

75. Simmonds, M.A. 1980. Evidence that bicuculline and picrotoxin act at separate sites to antagonize $\gamma$-aminobutyric acid in rat cuneate nucleus. Neuropharmacology. 19 : 39-45.

76. Sivam, S. P., T. Nabeshima and I. K. Ho. 1982. Acute and chronic effects of pentobarbital in relation to postsynaptic GABA receptors : a study with muscimol. J. Neurosci. Res. 7 : 37-47.

77. Skolnick, J. L. Barker, P., V. Moncada and S. M. Paul. 1981. Pentobarbital : dual actions to increase brain benzodiazepine receptor affinity. Science, $211: 1448-1450$.

78. Sonawane, B. R. S. J. Yaffe and B. H. Shapiro. 1980. Changes in mouse brain diazepam receptor binding after phenobarbital administration. Life Sci. 27 : 1335-1338.

79. Squires, R. F., D. I. Benson, C. Braestrup, J. Coupet, C.A.Klepner, V. Myers and B. Beer. 1979. Some properties of brain specific benzodiazepine receptors : new evidence for multiple receptors. Pharmacol. Biochem. Behav. $10: 825-830$.

80. Squires, R. F., J. E. Casida, M. Richardson and E. Saederup. 1983. [ ${ }^{35}$ S]t-butylbicyclophosphorothionate binds with high affinity to brain-specific sites coupled to $\gamma$ aminobutyric acid-A and ion recognition sites. Mol. Pharmacol. 23 : 326-336.

81. Study, R. E. and J. L. Barker. 1981. Diazepam and (-)-pentobarbital : Fluctuation analysis reveals different mechanisms for potentiation of $\gamma$-aminobutyric acid responses in cultured central neurons. Proc. Natl. Acad. Sci. USA. $78: 7180-7184$.

82. Supavilai, P. and M. Karobath. 1984. $\left[{ }^{35}\right.$ S]-tButylbicyclophosphorothionate binding sites are constituents of the $\gamma$-aminobutyric acid benzodiazepine receptor complex. J. Neurosci. $4: 1193-1200$.

83. Supavilai, P., A. Mannonen and M. Karoba- th. 1982. Modulation of GABA binding sites by CNS depressants and CNS convulsants. Neurochem. Int. $4: 259-268$.

84. Tatsuoka, Y., Y. Kato, K. Yoshida and H. Imura. 1984. In vivo effects of phenytoin and phenobarbital on GABA receptors in rat cerebral cortex and cerebellum. Neurosci. Lett. $46: 255-260$.

85. Trifiletti, R. R., A. M. Snowman and S. H. Snyder. 1985. Barbiturate recognition site on the GABA/benzodiazepine receptor complex is distinct from the picrotoxinin/TBPS recognition site. Eur. J. Pharmacol. 106 : 441-447.

86. Tzeng, S. and I. K.Ho. 1977. Effects of acute and continuous pentobarbital administration on the gamma-aminobutyric acid system. Biochem. Pharmacol. 26 : 699-704.

87. Verdoorn, T. A., A. Draguhn, S. Ymer, P. H. Seeburg and B. Sakmann. 1990. Functional properties of recombinant rat $\mathrm{GABA}_{\mathrm{A}}$ receptors depend upon subunit composition. Neuron. 4 : 919-928.

88. Waddell, W. J. and B. Baggett. 1973. Anesthetic and lethal activity in mice of the stereoisomers of 5-ethyl-5-(1-methylbutyl)barbituric acid (pentobarbital). Arch. Int. Pharmacodyn. $205:$ 40-44.

89. Whiting, P., R. M. McKernan and L. L. Iversen. 1990. Another mechanism for creating diversity in '-aminobutyrate type A receptors : RNA splicing directs expression of two forms of $z_{2}$ subunit, one of which contains a protein kinase $C$ phosphorylation site. Proc. Natl. Acad. Sci. USA. 87 : 9966-9970.

90. Wilson-Shaw, D., M. Robinson, C. Gambarana, R. E. Siegel and J. M. Sikela. 1991. A novel $y$ subunit of the $\mathrm{GABA}_{A}$ receptor identified using the polymerase chain reaction. FEBS Lett. $284: 211-215$.

91. Wong, E. H. F., L. M. F. Leeb-Lundberg, V I. Teichberg and R. W. Olsen. 1984. ;Aminobutyric acid activation of ${ }^{36} \mathrm{Cl}$ flux in rat hippocampal slices and its potentiation by barbiturates. Brain Res. 303 : 267-275.

92. Ymer, S., A. Draguhn, M. Köhler, P. R. Schofield and P. H. Seeburg. 1989a. Seque- 
nce and expression of a novel $\mathrm{GABA}_{\mathrm{A}}$ receptor $\alpha$ subunit. FEBS Lett. $258:$ 119-122.

93. Ymer, S., A. Draguhn, W. Wisden, P.Werner , K. Keinänen, P. R. Schofield, R. Sprengel, D. B. Pritchett and P. H. Seeburg. 1990. Structural and functional characterization of the $\gamma_{1}$ subunit of the $\mathrm{GABA}_{\mathrm{A}} /$ benzodiazepine receptors. EMBO J. 9 : 3261-3267.

94. Ymer, S., P. R. Schofield, A. Draguhn, P. Werner, M. Kohler and P. H. Seeburg. 1989 b. $\mathrm{GABA}_{A}$ receptor $\beta$ subunit heterogeneity: functional expression of cloned cDNAs. EMBO J. $8: 1665-1670$. 


\title{
鎮靜安眠藥: 成癔性與其研究現況
}

\author{
YI-TANG TSENG, SUSAN E. WELLMAN, AND I. K. HO(何英剛) \\ Department of Pharmacology and Toxicology, University of Mississippi Medical Center \\ Jackson, Mississippi 39216-4505, U.S.A.
}

摘 要

酒精,巴比妥類藥劑和benzodiazepines等中樞 神經系統抑制藥, 在人類和動物均具有同等效力。 依使用劑量的不同,這些藥劑對中樞神經系統會產 生不同程度的抑欝作用。當小劑量給藥時,這些鎭 靜安眠藥可減輕病人的焦慮和降低其自發性動作。 中等劑量則引發嗜睡, 相反的, 大量服用時則導致

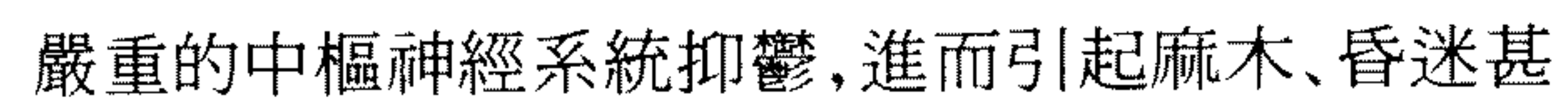
至死亡。這種依據劑量不同所引致的中樞神經系統 抑攀上的差異也是鎭靜安眠藥分級的一個共同特 性。這類藥物, 除了引起中樞神經系統抑㓡外, 向含 有藥理學上的某些性質,例如:促進肌肉鬆弛, 抗㾏 摹作用,和緩呼吸及降低體溫等。

長期的服用鎭靜安眠藥,往往造成服用者對這 些藥劑產生耐受性和依賴性,所謂的耐受性就是對 這些藥物作用的感受性因繼續的使用而降低, 或者 需服用更高劑量才能達到最初服用時的效果。至於 藥物耐受性歸結可分成兩種型態: 一種是傾向性藥 物耐受性(屬藥物動力的), 另一種則是功能性的藥 物耐受性(屬藥效的)。藥物依賴性則導因於生理功 能的一種修飾作用, 病人必需繼續不斷的使用該類 藥劑才能阻止脫癋徵狀的出現, 長期服用者如果突
然戒除該類藥物則會產生焦慮、軍眩、噁心、嘔吐、 失眠、抽動、發熱、譫安、顫抖、全身痙攣, 甚或死亡。

証據顯示, 鎭靜安眠藥, 例如benodiazepines, 巴比妥類藥劑和酒精等, 其某些藥理學上的作用可 能是藉著模擬 $\gamma$-胺基酪酸(GABA)的傳遞來達成, 然而, 這些藥劑在GABA系統上的作用機轉則仍 待探討, 即使如此, benzodiazepines的受體已經被 証實係GABA受體的一部分。關於巴比妥類藥劑, 雖然其在GABA系統上確切的結合位置晌未被定 出, 但是許多有力証據顯示巴比妥類藥劑和發厥藥 劑係結合在不同位置上,但這兩個結合位却彼此藉 著異位立體形式(allosteric)相互影響。至於酒精可 能是影響在多數的神經傳導系統上。

GABA胞突接合(synapse)在這些鎭靜安眠藥 之藥理效用上扮演一個重要的角色, 然而這些中樞 神經抑制藥對GABA胞突接合之藥理上和生化上 的影響則有所異同。這類藥物對GABA胞突接合 影響又會因不同腦部區域而有所差異。文獻上對這 方面的報導頗不一致,這些差異可能是研究者(a) 使用不同的動物模式(b)使用不同腦部區域(c)不同 的動物處理條件或 $(\mathrm{d})$ 不同技術所致。 